\title{
Uni Tavur and media education at UPNG
}

Uni Tavur, the award-winning journalism training newspaper at the University of PNG is the only newspaper in the South Pacific to have an 'editorial charter'. The paper also observes the Charter of Student Press Rights under the United Nations Convention on Freedom of Information.

\section{By DAVID ROBIE}

THE UNIVERSITY of Papua New Guinea has made a significant and valuable contribution to tertiary journalism education throughout the South Pacific for the past two decades. It has produced more than 150 graduates in that time, many of them in leading positions in the news media today.

Some UPNGgraduates also hold prominent positions in the media in other Pacific countries. For example, Solomon Islander Alfred Sasako is the South Pacific Forum's Public Information Officer in Suva, Oseah Philemon is the editor of the Post-Courier and Dominic Kakas is editor of The Independent. And Sorariba Nash, who was among the pioneering graduates, is now broadcast journalism lecturer. Among current graduates, Solomon Islander Campion Ohasio has returned to his country and is acting editor of the Solomons Voice while Colin Taimbari and Isaac Nicholas have already made names for themselves as successful police reporters on the Post-Courier.

According to recent research, 68 per cent of Papua New Guinean journalists have a tertiary qualification and this contrasts with countries such as Fiji which has just 16 per cent. ${ }^{2}$ The university has also produced most of the region's journalism education texts and manuals, including the three-volume News Manual by the late Peter Henshall, and David Ingram, both former lecturers, and more recently Nius Bilong Pasifik: Mass Media in the Pacific, edited by me. ${ }^{4}$

Print journalism at the university's new South Pacific Centre for Communication and Information in Development has undergone dramatic changes in less than four years. At the beginning of 1993, we had merely a pile of rusting 
typewriters and students were writing news stories by longhand. ${ }^{5}$ Two Macintosh Classic computers along with some desktop publishing software were donated by the Ministry of Communication and Information (a few months later the suppliers tried to repossess the computers because the ministry had failed to pay for them). At the time, the journalism training newletter Uni Tavur was a modest A4 format with no photographs printed on canary yellow paper. Its distribution was also limited, with little market penetration outside campus.

Throughout 1993 and 1994, the newsletter was consolidated as a professionally produced publication using PageMaker software, graphics and halftones. But the A4 format was retained because this was the only option available while printing at the University Printery - an operation that took almost two days for a circulation of 1500 .

It became increasingly clear that for the Journalism Studies component of SPCenCIID and for students themselves to really develop in this computer technological age, a quantum leap was needed in newspaper production. However, it was also equally clear that amid the climate of tertiary budgetary cuts in Papua New Guinea and their crippling impact on the university that we would need to be creative and innovative in finding ways to make the desired changes.

I embarked in 1994 on a three-pronged plan to turn Uni Tavur into a highly competitive and professional newspaper along the 'community newspaper' lines of some overseas countries - in other words selling advertising space to cover our printing and production costs, and distributing the paper free.

As the paper merely needed to break even, this took some of the financial pressure off. However, it would still be a herculean task to establish the paper's 


\section{DAVID ROBIE}

credentials as a viable advertising medium, especially when all student staff are part-time, including myself, a lecturer teaching four or five other courses as well.

First we established a local network for all computers in the desktop publishing program. Then I modified the At Ease program designed for educational needs with a multi-work station network. I designed a graduated access system suitable for reporters, subeditors and editors working in a sophisticated publishing program involving several titles besides the fortnightly newspaper Uni Tavur.

I followed this with a design revamp of Uni Tavur at the end of 1994 in preparation for a relaunch as a tabloid newspaper. In February 1995, thanks to the enthusiastic support of then Post-Courier general manager Alan Robinson, production manager Doug Teale and other staff we made the transition to publishing as a tabloid. As a commitment to the training of the country's future journalists, the Post-Courier - largest circulation newspaper in the South Pacific - agreed to print the paper at cost. We are grateful for the opportunity for students to gain experience at producing a real newspaper under the pressure of deadlines. Post administrative manager Luke Sela and SPCenCIID head Rhonda Eva launched the new newspaper with the first print run on 23 February 1995. Immediately the paper enjoyed considerable success and popularity as a tabloid and currently has a circulation of $2000 .^{6}$

In June 1995, Uni Tavur won an award for the best community/student newspaper in the Pacific Media Awards. ${ }^{7}$ The paper also won the 1995 Ossie Award best student publication honour with the judge, Max Suich, chief executive of the Sydney Independent Monthly, saying the paper was 'by far the most impressive' of the student publications: 'It has a level of maturity in its writing and editing and a concern with serious national issues that made it stand head and shoulders above the others.'

The newsroom works on a very professional basis. A new newsroom was completed in early 1995. A student editor and a chief-of-staff are selected and appointed each semester on the basis of a written application responding to an advertised job - just like in real life. The prospective editor has to 'sell' her or himself to get the job. These positions are chosen from among students on the advanced Print Production II or Advanced News Practice courses. Senior subeditors, who are on the introductory Print Production I course, are allocated tasks such as pictures editor, sports editor, features editor and so on by the editor in consultation with the print lecturer. ${ }^{8}$

The students conduct their editorial conference and assign rounds and stories just like any newspaper. My role as managing editor is really as a guide to the students - I teach the necessary editorial skills, ensure the production targets and deadlines are met, support the editorial conferences with continuous 
Uni Tavur is a campus-based community newspaper which will be distributed free fortnightly to readers as widely as economically possible. It is a journalism training newspaper with the following purposes:

1. To provide a vehicle for members of the University of Papua New Guinea community to communicate news and opinions to one another, subject only to constraints of space, public interest, topicality and readability, as determined by the print journalism teaching staff and appointed senior student editors of the South Pacific Centre for Communication and Information in Development (SPCenCIID).

2. To inform the people of the nation about issues affecting Papua New Guinea through high quality news reports, feature articles and analysis.

3. To promote a fairer and more tolerant society, and for an improved quality of life for the students and citizens of PNG.

4. To ensure, in particular, that the activities and concerns of the relatively poor and powerless are represented in news and opinion articles.

5. To inform the nation of important media and information developments, and to contribute to debate ethical and media issues.

6. To offer practical advice to students about community and academic life.

7. To avoid denigrating any individual or group unless the benefit to the general public from publishing such material exceeds the hurt to the individual or group concerned.

8. To pursue all these goals with a sense of humour, and with a warm delight in the diversity of life.

\section{Uni Tavur's editorial charter .}

evaluation of the students' work, reinforce the social responsibility and accountability of student journalists, explore ethical and professional dilemmas as they arise, and ensure the students follow the Papua New Guinea Journalists' Association code of ethics.

In terms of accountability and guidelines, Uni Tavur is the only newspaper in the South Pacific to have an 'editorial charter', a mechanism used increasingly in many countries to establish editorial quality. The paper also observes the Charter of Student Press Rights in accordance with the spirit of the United Nations Convention on Freedom of Information The newspaper's slogan is 'A conch shell ... the voice of truth and independence'.

After a period of consolidation for six issues as an eight-page publication in the first semester, Uni Tavur took another great leap forward in July 1995 with the introduction of a major new course, the 16-week graduate Certificate in 
Investigative Journalism. This meant the newspaper added an extra four-page liftout - the 'Insight Report' investigative supplement - each issue. But the improvements did not end there For the special Independence anniversary edition on 16 September 1996 , marking two decades of PNG as a sovereign nation, Uni Tavur produced a 24page issue with four-colour editorial and advertising content.

Financially, UniTavur came close to meeting its budget. Although the paper did not cover all our costs for the year, we had a very successful Independ-

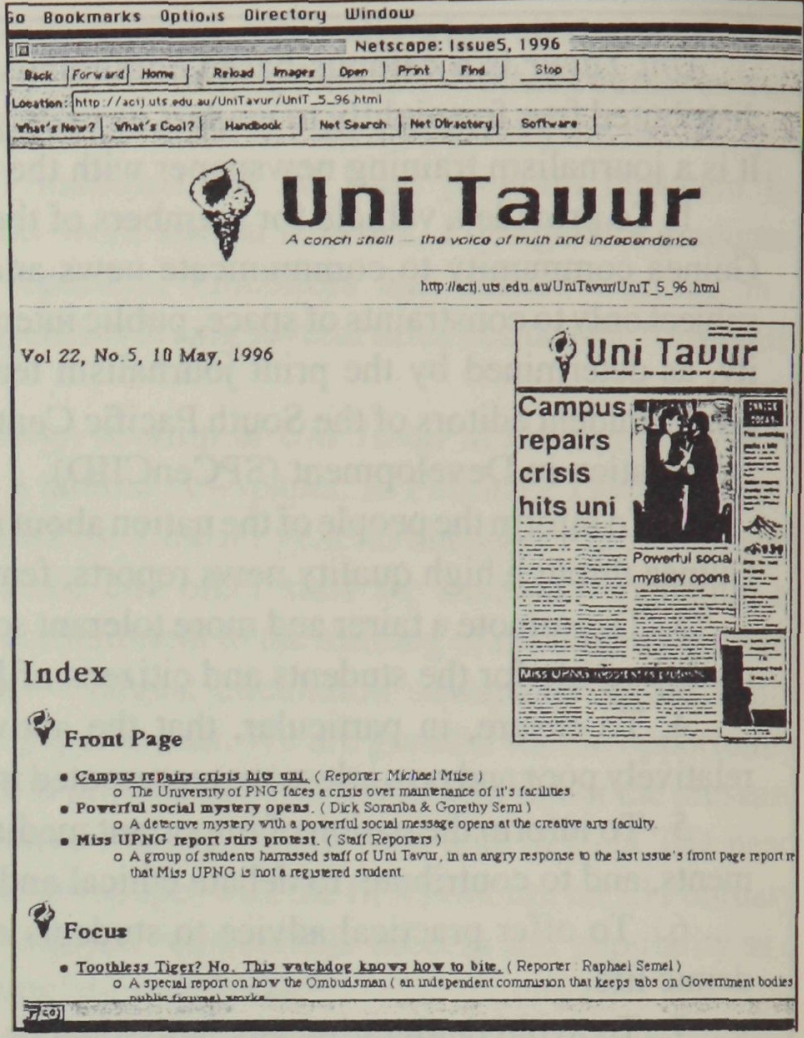

The Uni Tavur web site on the Internet. ence issue and the profit from that edition almost covered the issues published at a loss.

Now in 1996 Uni Tavur's emphasis has shifted to producing an electronic newspaper. In January, it became the first newspaper in the South Pacific to produce an electronic edition on a World Wide Web site. Thanks to longstanding cooperation with the Australian Centre for Independent Journalism at the University of Technology in Sydney, with which SPCenCIID has been negotiating a memorandum of understanding, the newspaper has been able to piggy-back on the ACIJ home page to have its own web site.

\section{The Web URL is: http://acij.uts.edu.au/UniT_Home.html}

This means that readers, researchers and media people on the Internet can get access to the latest Uni Tavur edition complete with stories, some graphics and photographs on their home PC. The new arrangement gives students an opportunity to work with the Internet and email software programs through the non-government and educational Pacific-wide communications coooperative. Pactok. This also provides an interactive alternative news service, 'Nius' and at a fraction of the cost of wire services for the daily and weekly press.

The Nius Web URL at Pactok is: http://www.pactok.net/docs/nius 
Students now graduating from UPNG have a level of computer literacy undreamed of three years ago in a Pacific tertiary institution. Many graduates can now produce a publication in their own right through the reporting and subediting stages. They also have some firsthand experience of the hard economic realities of advertising and distribution.

The publications produced by SPCenCIID include: Uni Tavur, a fortnightly tabloid newspaper covering campus, regional and national news and current affairs, and also South Pacific issues.

Ita Diba, a quarterly newsletter covering communications issues and the work of the university's South Pacific Centre for Communication and Information in Development.

Pacific Journalism Review, an annual or twice a year journal debating mass media, communications, journalism and related issues. This is subscribed to very widely by libraries and news media organisations in the region.

Campus Toktok, an occasional newsletter published in close association with Uni Tavur.

Nius Bilong Pasifik: Mass Media in the Pacific, a comprehensive resource book on the South Pacific news media with emphasis on Papua New Guinea. It includes a 40-page socio-economic and media country profile.

\section{Recommendations:}

Much of what has been described sounds very positive in terms of what SPCenCIID has achieved. However, the downside is that the journalism program has always been severely under-resourced at the university.

All computers have been donated from outside sources, not a single one being supplied by the university. I would like to stress here how grateful we are for the valuable direct financial support we have enjoyed from several organisations, notably the New Zealand High Commission. Post-Courier. UNESCO and Cuso through the Canada Fund. Without their support it would not have been possible to expand our program as dramatically as we have done. In the case of New Zealand, it helped found the journalism program in 1995 and funded it for three years. It has been heartening to have their support 20 years on.

But there are still many areas that SPCenCIID needs financial and material support. These are areas that realistically, given the budgetary cuts. cannot be provided from within the university. Some of these needs include:

Air conditioning and floor covering for the Uni Tarur new sroom to protect the computers and publication production.

Substantial funding for a major upgrade of the broadcasting studio and installation of a broadcast newsroom. 


\section{DAVID ROBIE}

- Funding for the expansion of the data base and development of an editorial library.

$\square$ Funding for a news-gathering vehicle for the Centre.

$\square$ Funding to underwrite field trips to enable students to make environmental and other journalistic assignments to other parts of PNG.

$\square$ Development funding for publications.

$\square$ Funding for specialised short courses.

SPCenCIID's program gives journalism students an innovative, challenging and wide-ranging basic vocational training and academic education. After they graduate, the responsibility for furthering their education and specialised training rests with the news media organisations. Some have been rising to this challenge, others have neglected their responsibility. And others have been blaming the university without making any commitment to journalism training themselves.

While some media organisations have shown a commitment to journalism training by working with closely with the centre through the Board of Journalism Studies, set up by the university in 1994, other media groups have conveniently ignored it.

Future plans for expanding the centre's program include more specialised mid-career short courses - such as investigative journalism, desktop publishing, environmental journalism and public affairs journalism - in partnership with media organisations. The investigative journalism certificate course began in 1995 and desktop publishing started in June 1996 with assistance from AusAID.

Papua New Guinea is rich in human and media technological resources, and ideally there should be close cooperation between the media organisations and the educators. The country should rely on home-grown expertise where possible.

And there should be pride in the progress of the centre's accomplishments in journalism education as after all it is both the pioneer and the longest standing journalism training institution in the South Pacific.

\section{Notes:}

${ }^{1}$ Memorandum from Benjamin Naing, Deputy Registrar (Academic), UPNG, to David Robie, 4 December 1995 in response to the author's request: 110 one-year diplomates in Journalism graduated up to 1985; 13 two-year Diploma in Media Studies graduated since 1990; 23 graduated with four-year Bachelor of Journalism degrees since 1989.

${ }^{2}$ Layton, Suzanna, 'The demographics of diversity: profile of Pacific Island journalists', Australian Studies in Journalism, Vol 4, p 137, 1995.

3 Henshall, Peter and David Ingram, The News Manual: A Training Book for Journalists; Vol 1: Basic Techniques; Vol 2: Advanced Reporting; Vol 3: Ethics and the 100 PACIFIC JOURNALISM REVIEW 3:2 1996 
Law, Port Moresby: Poroman Press, published with financial help from the Pacjourn project of UNESCO, 1991.

${ }^{4}$ Robie, David (ed), Nius Bilong Pasifik: Mass Media in the Pacific, Port Moresby: University of PNG Press, 1995, 274 pp.

${ }^{5}$ Robie, David (producer) and Jameson Bere (director), Uni Tavur: Two Decades of a Student Press, 17 minute video produced to mark the 20th anniversary of the founding of the newspaper Uni Tavur, 1994.

${ }^{6}$ Uni Tavur, Vol 21 No 1, 24 February 1995.

' See Uni Tavur, Vol 21, No 7, 21 July 1995.

${ }^{8}$ See Development Communications: Journalism, Public Relations, Library and Information Studies 1996 Handbook, Port Moresby: South Pacific Centre for Communication and Information in Development (SPCenCIID).

$\square$ David Robie is Lecturer in Print Journalism at the University of Papua New Guinea's South Pacific Centre for Communication and Information in Development (SPCenCIID). This paper was presented at the 'Freedom at the Crossroads: The Media and the Constitution' Seminar under the title 'Electronic Student Newspaper: Uni Tavur and Print Media Education at UPNG', Sir John Guise Indoor Stadium, 29 February-1 March 1996. drobie@pactok.peg.apc.org

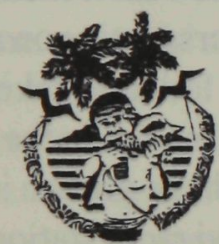 \\ SOUTH PACIFIC CENTRE FOR COMMUNICATION AND INFORMATION IN DEVELOPMENT}

$\square$ Largest and oldest Pacific journalism school.

$\square$ Education of journalism, public relations, library and information professionals.

$\square$ Research into media and information issues.

$\square$ Publisher of newsletters, resource books and the fortnightly newspaper Uni Tavur.

$\square$ Professional short courses and consultancies.

UNIVERSITY OF PAPUA NEW GUINEA

Box 320, Uni PO, NCD. TeVFax: (675) 3267191 